\title{
Perbedaan Efek Antibakteri Ekstrak Etanol Lada Hitam (Piper Nigrum L.) dengan Ekstrak Etanol Lada Putih (Piper Nigrum L.) terhadap Streptococcus Mutans secara In Vitro
}

The Differences Antibacterial Effects of Black Pepper (Piper nigrum L.) Ethanol Extracts with White Pepper (Piper nigrum L.) Ethanol Extracts against Streptococcus mutans In vitro

Irresta Zainistya Putri ${ }^{1}$, M. Chair Effendi ${ }^{1}$, Sumarno ${ }^{2}$

1. Program Studi Pendidikan Dokter Gigi, Fakultas Kedokteran Gigi Universitas Brawijaya

2. Program Studi Pendidikan Dokter, Fakultas Kedokteran Gigi Universitas Brawijaya Jl. Veteran Malang 65145

E-mail: chaireffendi@gmail.com

\begin{abstract}
Abstrak
Lada putih (Piper nigrum L.) mengandung fenol dan alkaloid lebih banyak daripada lada hitam (Piper nigrum L.). Streptococcus mutans merupakan bakteri rongga mulut yang menghasilkan zat asam dan menyebabkan karies gigi. Tujuan: untuk mengetahui perbedaan efek antibakteri ekstrak etanol lada hitam dan lada putih terhadap Streptococcus mutans secara in vitro. Metode: eksperimental laboratorik dengan metode difusi agar sumuran untuk mendapatkan zona hambat. Konsentrasi ekstrak etanol lada hitam dan lada putih yang digunakan adalah $0 \%, 6,25 \%, 12,5 \%, 25 \%$, 50\%, dan $100 \%$. Hasil: zona hambat pada lada hitam terbentuk pada konsentrasi $100 \%$, zona hambat pada lada putih terbentuk pada konsentrasi 12,5\%,25\%,50\%, dan 100\%. Analisis data One Way ANOVA menunjukkan terdapat perbedaan signifikan pada perubahan konsentrasi ekstrak etanol lada hitam dan lada putih terhadap zona hambat Streptococcus mutans $(p<0,05)$. Uji korelasi Pearson menunjukkan hubungan kuat dan berbanding lurus antara konsentrasi ekstrak etanol lada hitam $(0,882)$ dan lada putih $(0,812)$ dengan zona hambat Streptococcus mutans. Hasil uji regresi efek ekstrak etanol lada hitam $77,8 \%\left(R^{2}=0,778\right)$ dan ekstrak etanol lada putih $65,9 \%\left(R^{2}=0,659\right)$. Uji post hoc Tukey menunjukkan terdapat perbedaan signifikan antara ekstrak etanol lada hitam konsentrasi $6,25 \%, 12,5 \%, 25 \%, 50 \%, 100 \%$ dengan ekstrak etanol lada putih konsentrasi $6,25 \%, 12,5 \%, 25 \%$, $50 \%, 100 \%$ terhadap zona hambat Streptococcus mutans. Kesimpulan: terdapat perbedaan efek antibakteri antara ekstrak etanol lada hitam dengan ekstrak etanol Lada putih terhadap zona hambat Streptococcus mutans secara in vitro.
\end{abstract}

\section{Kata Kunci : Streptococcus Mutans, Lada Hitam, Lada Putih, Zona Hambat}




\begin{abstract}
White pepper (Piper nigrum L.) containing phenol and alkaloid more than black pepper (Piper nigrum L.). Streptococcus mutans is a bacterium of the oral cavity that produce acid and cause dental caries. Objective: To determine differences in the antibacterial effect of the ethanol extract of black pepper and white pepper against Streptococcus mutans in vitro. Methods: The experimental laboratory with agar diffusion method to obtain pitting inhibition zone. The concentration of ethanol extract of black pepper and white pepper used is $0 \%, 6.25 \%, 12.5 \%, 25 \%, 50 \%$ and 100\%. Result: The inhibition zone on black pepper formed at $100 \%$ concentration, inhibition zone on white pepper is formed at a concentration of $12.5 \%, 25 \%, 50 \%$ and $100 \%$. One Way ANOVA analysis of the data showed significant differences in changes in the concentration of ethanol extract of black pepper and white pepper against Streptococcus mutans inhibition zone $(p<0.05)$. Pearson correlation test showed a strong relationship between the concentration and proportional to the ethanol extract of black pepper (0.882) and white pepper $(0,812)$ with a zone of inhibition of Streptococcus mutans. Results of regression test the effects of ethanol extract of black pepper $77.8 \%(R 2=0.778)$ and the ethanol extract of white pepper $65.9 \%(R 2=0.659)$. Tukey post hoc test showed a significant difference between the ethanol extract of black pepper concentration of $6.25 \%, 12.5 \%, 25 \%, 50 \%, 100 \%$ ethanol extract of white pepper with a concentration of $6.25 \%, 12.5 \%, 25 \%, 50 \%, 100 \%$ of the inhibitory zone Streptococcus mutans. Conclusion: there is a difference between the antibacterial effect of the ethanol extract of black pepper and white pepper with ethanol extract of the inhibitory zone Streptococcus mutans in vitro.
\end{abstract}

\title{
Keywords: Streptococcus Mutans, Black Pepper, White Pepper, Inhibition Zone
}




\section{PENDAHULUAN}

Di Indonesia, dikenal beberapa macam jenis lada yang diperdagangkan yaitu lada hijau, merah, hitam, dan putih. ${ }^{1}$ Warna lada yang berbeda-beda disebabkan perbedaan waktu panen dan pengolahan setelah panen. Pengolahan yang berbeda menyebabkan kandungan setiap macam warna lada juga berbeda meskipun berasal dari jenis lada yang sama.

Di dalam buah lada terdapat kandungan yang bermanfaat bagi tubuh salah satunya sebagai antibakteri. Antibakteri yang ada pada buah lada adalah fenol, alkaloid, dan minyak esensial. $^{2}$ Hasil resultan kerja dari bahan tersebut akan merusak dinding sel dan DNA bakteri sehingga bakteri akan lisis.

Streptococcus mutans merupakan flora normal rongga mulut, namun akan menjadi patogen bila jumlahnya terus meningkat. Streptococcus mutans bersifat asidogenik yaitu menghasilkan asam, asidodurik yaitu mampu tinggal pada lingkungan asam, dan menghasilkan suatu polisakarida yang lengket disebut dextran. Oleh karena kemampuan ini, Streptococcus mutans bisa menyebabkan bakteri lain menempel di enamel gigi, mendukung pertumbuhan bakteri asidodurik yang lainnya, dan asam yang dihasilkan dapat melarutkan enamel gigi. ${ }^{3}$

Enamel yang larut merupakan awal terjadinya karies gigi. Karies gigi merupakan satu dari penyakit gigi dan mulut yang paling umum terjadi di Indonesia. Berdasarkan Survei Kesehatan Rumah Tangga (SKRT) tahun 2004, tingkat karies di Indonesia sebesar 90,05\%. Upaya pencegahan karies bisa dengan aplikasi fluoride topikal atau menggunakan sealant. Akan tetapi, karena perawatannya membutuhkan biaya dan bantuan dokter gigi maka muncul alternatif penggunaan bahan alami sebagai pencegahan terhadap karies.

Lada merupakan salah satu bahan alami yang mudah didapat dan harganya terjangkau. Dari beberapa macam lada, lada yang biasa ditemui sehari-hari adalah lada hitam dan lada putih.

\section{Tujuan}

Untuk mengetahui apakah terdapat perbedaan efek antibakteri antara ekstrak ethanol lada hitam dan lada putih terhadap Streptococcus mutans.

\section{METODE PENELITIAN}

Penelitian ini merupakan penelitian murni dengan Posttest Only Control Group Design secara in vitro menggunakan metode difusi sumuran untuk mendapatkan zona hambat. Sampel penelitian ini adalah Streptococcus mutans yang didapat dari biakan di laboratorium Fakultas Kedokteran Universitas Brawijaya. Variabel bebas penelitian ini adalah ekstrak etanol lada hitam dan ekstrak etanol lada putih dengan konsentrasi masing-masing $100 \%$, 50\%, 25\%, $12,5 \%$, 6,25\%, dan 0\%. Variabel terikat penelitian ini adalah pertumbuhan bakteri Streptococcus mutans diukur dengan zona hambat yang terbentuk dalam milimeter dengan menggunakan kaliper. Penelitian ini dilakukan di laboratorium FKUB pada bulan November 2013-Februari 2014.

Identifikasi bakteri Streptococcus mutans dilakukan menggunakan pewarnaan Gram, tes katalase, dan tes optochin. Pewarnaan Gram dilakukan dengan cara meneteskan kristral violet, lugol, alkohol 96\%, dan safranin secara bergantian pada preparat Streptococcus mutans. Setiap reagen dibilas menggunakan air mengalir, kemudian preparat diamati menggunakan mikroskop pembesaran 1000x. 
Tes katalase dilakukan dengan cara meneteskan $\mathrm{H} 2 \mathrm{O} 2$ 3\% pada Streptococcus mutans. Tes optochin dilakukan menggunakan Streptococcus mutans yang digoreskan pada Chocolate Agar Plate kemudian diletakkan disk optochin pada agar tersebut. Zona hambat diamati setelah plate diinkubasi selama 24 jam pada suhu $37^{\circ}$.

Lada hitam dan lada putih masing masing 100 gram dihaluskan menggunakan blender, dimasukkan ke dalam tabung erlenmeyer, ditambahkan $900 \mathrm{ml}$ etanol 96\%, kemudian dikocok sampai homogen. Larutan disimpan pada suhu kamar selama 24 jam, lalu disaring dengan kertas filter hingga diperoleh cairan yang bebas dari partikel kasar. Selanjutnya dievaporasi untuk memisahkan pelarut etanol menggunakan alat rotary evaporator pada temperatur $65^{\circ} \mathrm{C}$ (sesuai titik didih etanol) hingga semua pelarut terpisah dan didapatkan cairan ekstrak yang kental dengan konsentrasi $100 \%$.

Uji Antibakteri dilakukan dengan menyiapkan BHI agar yang dibuat dari 28 gram nutrient agar dan $1 \mathrm{~L}$ air suling. Medium dilarutkan dan diautoklaf pada suhu $121^{\circ} \mathrm{C}$ selama 15 menit. Tambahkan $10 \mu \mathrm{l}$ kultur bakteri yang diambil dari BHI broth, lalu tuangkan ke dalam plate dan didinginkan hingga suhu mencapai $45^{\circ} \mathrm{C}$. Melakukan pengenceran seri ekstrak etanol lada hitam dan lada putih. Tabung 1 ekstrak etanol I 100\% $5 \mathrm{ml}$. Tabung 2 ekstrak etanol $100 \% 5 \mathrm{ml}$ ditambah $5 \mathrm{ml}$ aquadest steril. Tabung 3 ekstrak etanol 50\% $5 \mathrm{ml}$ ditambah 5 $\mathrm{ml}$ quadest steril. Tabung 4 ekstrak etanol $25 \% 5 \mathrm{ml}$ ditambah $5 \mathrm{ml}$ aquadest steril. Tabung 5 ekstrak etanol 12,5\% $5 \mathrm{ml}$ ditambah $5 \mathrm{ml}$ aquadest steril. Tabung 6 aquadest $5 \mathrm{ml}$. Dilakukan pembuatan lubang sumuran dengan perforator berdiameter $6 \mathrm{~mm}$ sebanyak 6 buah. Teteskan ekstrak etanol lada hitam dengan 6 konsentrasi berbeda dengan mikropipet sebanyak $10 \mu \mathrm{l}$ ke dalam masingmasing lubang sumuran pada plate pertama. Teteskan ekstrak etanol lada putih dengan 6 konsentrasi berbeda dengan mikropipet sebanyak $10 \mu \mathrm{l}$ ke dalam masing-masing lubang sumuran pada plate kedua. Inkubasi plate yang berisi BHI agar dalam inkubator dengan suhu $37^{\circ} \mathrm{C}$ selama $18-24$ jam. Setelah diinkubasi, hitung diameter daerah hambat pertumbuhan Streptococcus mutans dengan menggunakan kaliper. Dilakukan uji Anova One Way, uji korelasi Pearson, dan uji regresi. Untuk mengetahui adanya perbedaan antara ekstrak etanol lada hitam dengan ekstrak etanol lada putih maka dilakukan uji T tidak berpasangan.

\section{HASIL PENELITIAN}

Hasil tes pewarnaan gram didapatkan gambaran sel bakteri Streptococcus mutans berbentuk bulat (kokus), berantai, berwarna ungu yang menunjukkan bakteri gram positif. Hasil tes katalase, pada koloni bakteri tidak terlihat adanya gelembung. Hal ini menunjukkan bahwa bakteri bersifat katalase negatif dan merupakan golongan Streptococcus. Hasil tes optochin, tidak ada zona hambat di sekeliling disk optochin. Hal ini menunjukkan bahwa hasil tes optochin negative dan merupakan bakteri Streptococcus mutans.

Lada hitam menghasilkan ekstrak yang keruh berwarna coklat kehitaman, sedangkan lada putih menghasilkan ekstrak keruh berwarna coklat muda kehijauan. Hasil pengukuran diameter zona hambat ekstrak etanol lada hitam dan ekstrak etanol lada putih terhadap Streptococcus mutans tampak pada tabel 1. 
Tabel 1. Hasil Pengukuran Rerata Diameter Zona Hambat Ekstrak Etanol Lada Hitam dan Ekstrak Lada Putih terhadap Streptococcus mutans

\begin{tabular}{|c|c|c|c|}
\hline \multirow[t]{2}{*}{ Konsentrasi } & \multirow[t]{2}{*}{ Pengulangan } & \multicolumn{2}{|c|}{$\begin{array}{c}\text { Mean } \pm \text { SD } \\
\text { (Zona Hambat, mm) }\end{array}$} \\
\hline & & Lada Hitam & Lada Putih \\
\hline $0 \%$ & 3 & $0 \pm 0,000$ & $0 \pm 0,000$ \\
\hline $6,25 \%$ & 3 & $0 \pm 0,000$ & $0 \pm 0,000$ \\
\hline $12,5 \%$ & 3 & $0 \pm 0,000$ & $7,35 \pm 0,050$ \\
\hline $25 \%$ & 3 & $0 \pm 0,000$ & $8,7 \pm 0,161$ \\
\hline $50 \%$ & 3 & $0 \pm 0,000$ & $10,18 \pm 0,220$ \\
\hline
\end{tabular}

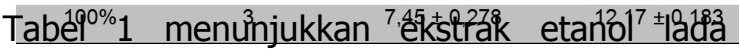

hitam dengan tiga kali pengulangan pada konsentari $0 \%, 6,25 \%, 12,5 \%, 25 \%, 50 \%$, tidak terbentuk zona hambat. Zona hambat terbentuk pada konsentrasi 100\%. Pada ekstrak etanol lada putih dengan tiga kali pengulangan, konsentrasi $0 \%$ dan 6,25\%, tidak terbentuk zona hambat. Zona hambat terbentuk pada $12,5 \%, 25 \%, 50 \%, 100 \%$.

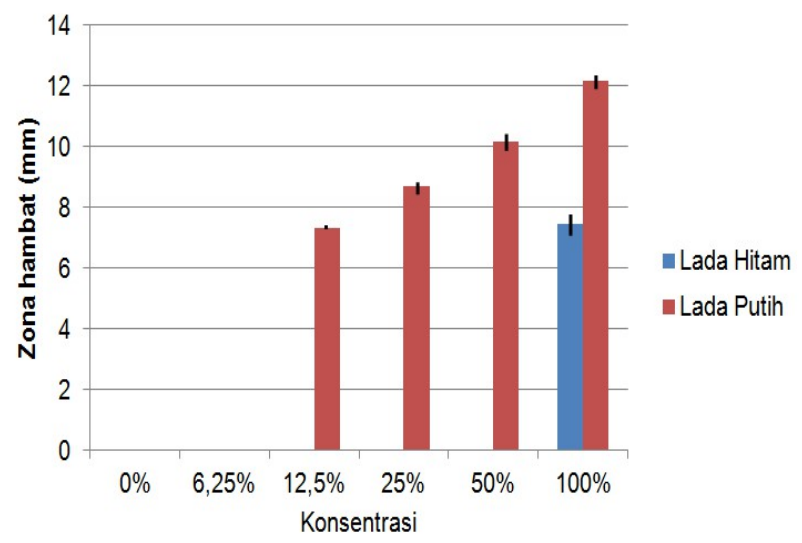

Gambar 1. Grafik Rerata Diameter Zona Hambat Ekstrak Etanol Lada Hitam dan Ekstrak Etanol Lada Putih terhadap Streptococcus mutans

Grafik pada gambar 1 menunjukkan terdapat perbedaan zona hambat antara ekstrak etanol lada hitam dengan ekstrak etanol lada putih. Semakin meningkat konsentrasi ekstrak, diameter zona hambat juga semakin besar.

Berdasarkan hasil uji normalitas Shapiro-Wilk, angka signifikansi pada ekstrak etanol lada hitam adalah 0,584 ( $p>0,05)$, angka signifikansi pada ekstrak etanol lada putih adalah $0,581(p>0,05)$, sehingga disimpulkan bahwa rerata diameter zona hambat ekstrak etanol lada hitam dan lada putih berdistribusi normal. Berdasarkan uji homogenitas varians Levene, angka signifikansi pada ekstrak etanol lada hitam 0,083 ( $p>0,05)$, angka signifikansi pada ekstrak etanol lada putih 0,063 ( $p>0,05)$, sehingga dapat disimpulkan bahwa data rerata diameter zona hambat ekstrak etanol lada hitam dan lada putih memiliki varians yang homogen. Berdasarkan uji korelasi Pearson, angka signifikansi pada ekstrak etanol lada hitam 0,000 $(p<0,05)$, dan memiliki kekuatan korelasi yang kuat $(r=0,882)$ dengan arah korelasi positif. Angka signifikansi pada ekstrak etanol lada putih $0,000(p<0,05)$, dan memiliki kekuatan korelasi yang kuat $(r=0,812)$ dengan arah korelasi positif. Sehingga dapat disimpulkan bahwa peningkatan kosentrasi ekstrak etanol lada hitam dan lada putih akan memperbesar diameter zona hambat. Berdasarkan uji regresi ekstrak etanol lada hitam, didapatkan $R$ square $\left(R^{2}\right)$ sebesar 0,778 yang berarti bahwa efektivitas pemberian ekstrak etanol lada hitam terhadap rerata zona hambat Streptococcus mutans adalah sebesar 77,8\%. Uji regresi ekstrak etanol lada putih, didapatkan $R$ square $\left(R^{2}\right)$ sebesar 0,659 yang berarti bahwa efektivitas pemberian ekstrak etanol lada putih terhadap rerata zona hambat Streptococcus mutans adalah sebesar $65,9 \%$. Berdasarkan uji One Way ANOVA, angka signifikan pada ekstrak etanol lada hitam 0,000 $(p<0,05)$, pada ekstrak etanol lada putih, didapatkan angka signifikan 0,000 $(p<0,05)$, sehingga dapat disimpulkan bahwa terdapat perbedaan yang signifikan antara ketujuh kelompok perlakuan yaitu ekstrak etanol lada hitam dan lada putih masing-masing konsentrasi $0 \%$ (kontrol negatif), 6,25\%, $12,5 \%, 25 \%, 50 \%, 100 \%$, kontrol positif terhadap rerata diameter zona hambat. 
Tabel 2. Hasil Uji T Tidak Berpasangan Ekstrak Etanol Lada Hitam dan Ekstrak Etanol Lada Putih

\begin{tabular}{|c|c|c|}
\hline \multicolumn{2}{|c|}{ Konsentrasi } & \multirow{2}{*}{$\begin{array}{c}\text { Angka } \\
\text { Signifikansi }\end{array}$} \\
\hline Lada Hitam & Lada Putih & \\
\hline $0 \%$ & $0 \%$ & 1,000 \\
\hline $6,25 \%$ & $6,25 \%$ & 1,000 \\
\hline $12,5 \%$ & $12,5 \%$ & 0,000 \\
\hline $25 \%$ & $25 \%$ & 0,000 \\
\hline $50 \%$ & $50 \%$ & 0,000 \\
\hline $100 \%$ & $100 \%$ & 0,000 \\
\hline \multicolumn{3}{|c|}{$\begin{array}{l}\text { Berdasarkan tabel 2, terdapat perbedaan } \\
\text { bermakna antara zona hambat ekstrak etanol } \\
\text { lada hitam dengan ekstrak lada putih pada }\end{array}$} \\
\hline
\end{tabular}

\section{PEMBAHASAN}

Pada penelitian ini didapat bahwa ekstrak lada hitam dan lada putih memiliki efek antibakteri terhadap Streptococcus mutans. Hal ini dikarenakan lada hitam dan lada putih memiliki kandungan fitokimia yaitu fenol (flavonoid, tanin), alkaloid (piperin, piperamid), dan minyak essensial. ${ }^{2}$ Fenol dapat mengganggu struktur tiga dimensi protein menjadi struktur acak. Hal ini mengakibatkan protein tidak mampu menjalankan fungsinya. Flavonoid dapat berinteraksi dengan DNA bakteri, merusak protein ekstraseluler, dan protein yang larut menyebabkan terjadinya kerusakan permeabilitas dinding sel bakteri, mikrosom, dan lisosom. ${ }^{4}$ Mekanisme kerja tannin dengan mengikat adhesin, menghambat kerja enzim, merusak membran sel, dan mengganggu komplek dinding sel bakteri. ${ }^{5,6}$

Alkaloid memiliki kemampuan mengganggu komponen penyusun peptidoglikan pada sel bakteri, sehingga dinding sel bakteri tidak terbentuk secara utuh. ${ }^{7}$ Mekanisme antibakteri piperin dengan mengganggu sinteris DNA dan dinding sel bakteri. $^{8}$ Sedangkan minyak esensial bekerja dengan merusak membran sel bakteri. ${ }^{5}$ Hasil resultan kerja ketiga zat kimia tersebut akan merusak dinding sel dan DNA sehingga terjadi lisis bakteri. Dilihat dari mekanisme kerja yang dapat menghambat sintesis dinding sel, memecah enzim dinding sel, mengganggu penyusun peptidoglikan, dan merusak membran sel membuat lada hitam dan lada putih memiliki kemampuan untuk membunuh bakteri (bakterisidal). ${ }^{9}$

Terdapat perbedaan proses setelah panen antara lada hitam dengan lada putih. Setelah dipanen lada putih langsung direndam untuk mencegah terjadinya oksidasi zat polifenol menjadi senyawa polimer hidroksikuinon oleh enzim polifenolase yang menyebabkan warna buah lada menjadi coklat. Berbeda dengan lada hitam yang langsung dijemur, ditambah dengan banyaknya kontak dengan oksigen saat penjemuran membuat oksidasi fenol bertambah. ${ }^{10}$ Hal ini membuat kandungan fenol lada putih lebih besar dari lada hitam. ${ }^{11}$ Sehingga terdapat perbedaan antara efek pemberian ekstrak etanol lada hitam dengan ekstrak etanol lada putih terhadap Streptococcus mutans.

\section{KESIMPULAN}

Terdapat perbedaan antara efek antibakteri ekstrak etanol lada hitam dengan ekstrak etanol lada putih terhadap pertumbuhan Streptococcus mutans. Terbentuk zona hambat Streptococcus mutans dengan pemberian ekstrak etanol lada hitam dan ekstrak etanol lada putih berbagai konsentrasi. Ekstrak etanol lada putih membentuk zona hambat Streptococcus mutans lebih besar dibandingkan ekstrak etanol lada hitam.

\section{Saran}


Perlu adanya penelitian lebih lanjut untuk mengetahui dosis terapeutik, dosis toksis, dan efek samping yang mungkin timbul pada penggunaan ekstrak etanol lada hitam dan ekstrak etanol lada putih. Perlu adanya penelitian lebih lanjut mengenai pengaplikasian ekstrak etanol lada hitam dan ekstrak etanol lada putih untuk obat kumur atau pasta gigi.

\section{DAFTAR PUSTAKA}

1. Kanisius. 2007. Bercocok Tanam Lada. Yogyakarta: Penerbit Kanisius.

2. Trivedi, M. N., Khemani, A., Vachhani, U. D., Shah, C. P., Santani, D. D. 2011. Pharmacognistic, Phytochemical Analysis and Antimicrobial Activity of Two Piper Species. India: Pharmacie Globale.

3. Jawetz, E., Melnick, J.L., Adelberg, E. A. 2007. Medical Microbiology. California: McGraw-Hill.

4. Douglas, K. A. 2005. Raisins As A Functional Food for Oral Health. Available from:

URL; http://www.sciencedaily.com/release s/2005/06/050608061403.html diakses tanggal 12 Agustus 2012.

5. Cowan, Marjorie Murphy. 1999. Plant Products as Antimicrobial Agents Vol. 12, No. 4 p. 564-582. USA: Clinical Microbiology Reviews.

6. Duke, J. A. Vitis vinifera L. Available from: URL;

http://host.purdue.edu/newcrop/duke en ergy/vitis_vinifera.html diakses tanggal 12 Agustus 2012.

7. Robinson, T. 1991. Kandungan Organik Tumbuhan Tingkat Tingi p. 132. Bandung: ITB.
8. Rani, S. K. S., Saxena, Neeti., Udaysree. 2013. Antimicrobial Activity of Black Pepper (Piper nigrum L.) Vol. 7, p. 87-90. India: Global Journal of Pharmacology.

9. Kee, Joyce L., Hayes, Evelyn R. 1996. Farmakologi. Pendekatan Proses Keperawatan. Jakarta: EGC.

10. Towaha, Juniaty., Ferry, Yulius. 2011. Prospek Pengembangan Teknologi Pengolahan Lada Hijau di Petani Vol. 10, No 1. Sukabumi: Persepektif.

11. Shan, Bin., Cai, Yizhong Z., Sun, Mei., Corke, Harold. 2005. Antioxidant Capacity of 26 Spice Extracts and Characterization of Thei phenol Constituents. Hong Kong: American Chemical Society. 